\title{
Biochemical changes in Mucuna sloanei (ukpo) seeds induced by six pathogenic fungi and comparative analysis of the pathogenic fungi
}

\section{U. N. Emiri ${ }^{1}$ and E. B. Enaregha ${ }^{2}$}

\author{
${ }^{1}$ Department of Agricultural Education. Isaac Jasper Boro College of Education. \\ Sagbama. Bayelsa State. Nigeria. Email: ucheemiri@gmail.com. \\ ${ }^{2}$ Department of Biology Education. Isaac Jasper Boro College of Education. \\ Sagbama. Bayelsa State. Nigeria.
}

\begin{abstract}
Biochemical changes in Mucuna sloanei Fawc. \& Rendle (Fabaceae) seeds induced by six pathogenic fungi and comparative analysis of the pathogenic fungi were investigated. The fungal pathogens isolated from partially rotted seeds of M. sloanei seeds include Rhizopus stolonifer, Aspergilus flavus, Aspergillus niger, Penicillium italicum, Alternaria altermata and Fusarium oxysporum. These fungi were used as test fungi to inoculate healthy $M$. sloanei seeds aseptically. The results of proximate analysis in $(\% \mathrm{w} / \mathrm{w}) / 100 \mathrm{~g}$ of seeds inoculated with the test fungi and uninoculated (control) seeds carried out revealed that there was a significant increase $(\mathrm{P}<0.05)$ in moisture, ash, lipid and carbohydrate content of seeds inoculated with the test fungi, relative to uninoculated (control) seeds. While fiber and protein content decreased in fungi inoculated seeds relative to uninoculated seeds. There was a significant difference $(\mathrm{P}<0.05)$ in mineral content evaluated. Calcium, phosphorus and sodium increased in seeds inoculated with the test fungi relative to the uninoculated, while iron, potassium and magnesium decreased in seeds inoculated with the test fungi. Phytochemical (anti-nutrient) contents (tannin, saponins, total oxalate and cynogenic glucoside) increased in the fungi inoculated seeds, relative to uninoculated seeds. Significant differences also occurred among the test fungi. Fusarium oxysporum, Alternaria altermata and Penicillium italicum appeared to induce more changes in proximate and mineral composition. Penicillium italicum also recorded the highest increase in phytochemical content (tannin, saponin and total oxalate) in seeds inoculated with test fungi relative to the uninoculated (control) seeds.
\end{abstract}

Keyword: Biochemical; Mucuna sloanei; Proximate; Fungi; Phytochemical.
Received

February 19, 2020

Accepted

March 18, 2020

Available on line on

March 20, 2020

Released

April 30, 2020

Full Text Article

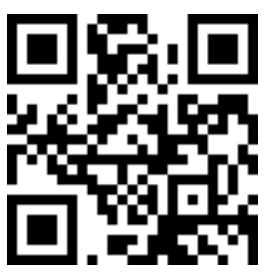

ORCID

(1) 0000-0003-2964-8970

U. N. Emiri

(1) 0000-0002-9213-6129

E. B. Enaregha 


\section{Introduction}

Macuna is a genus of about one hundred (100) accepted species of climbing vines and shrubs of the Family Fabaceae, found worldwide in the wood lands of tropical areas (Bressani et al., 2002). Like other legumes, Mucuna plants bear pods. The seed pods are covered with microscopic velvety hairs (called trichomes) that can be extremely painful if they get into your eyes or could cause itchy blister when they come in contact with the skin. They are generally bat pollinated and produce seeds that are buoyant sea beans. They have a characteristics three-layered appearance, appearing like the eyes of a large mammal in some species and like a humburger in others, most notably Mucuna sloanei Fawc. \& Rendle.

Mucuna sloanei is used by the Igbo community in Sub-Sahara Africa as condiment or part of the main dish (Ukachukwu et al., 2002). Seeds of Mucuna sloanei popularly called ukpo are used as soup thickener and vegetable oil, beverages and food items (Wayekeche et al., 2003). Its seeds are cracked by hitting with a hard object before cooking, then dehulled, ground, mixed with palm oil to obtain yellow powder and marked as soup thickener. All parts of Mucuna sloanei plant are reported to possess phytochemicals of high medicinal value and veterinary importance and also constitute as an important raw material in Ayurvedic and folk medicines.

Hydrothermal treatment, fermentation and germination have been shown to be most effective in reducing the anti-nutrients of the seeds. Several anti-nutritional compounds of the seeds serve in health care and considerable attention has been drawn towards their antioxidant properties and potential health benefits. (Adebowale et al., 2005). It has nutritional potentials as a rich source of protein $23 \%-35 \%$ (Bressani 2002). The functional properties of seed flour assume importance in the development of food product. Proteins and starch are the main contributors for change in functional properties such as bulk density, oil, water absorption and least galatin concentration. The seeds of Mucuna sloanei posses good functional properties and in vitro protein digestibility (Adebowale et al., 2005).

Beside typical medicinal properties, several phytochemicals of Mucuna sloanei seeds serve in health care in a variety of ways. The phytic acid of M. sloanei possesses antioxidant, anti-carcinogenic and hypoglycemic activities (Graf and Eaton 1990; Richard and Thompson, 1997) and are effective at low concentrations. Saponins are recently shown to have hypocholestrolemic as well as anti-carcinogenic effect (Koratkar and Rao, 1997). Tannins are also known to possess health benefits, where they are 15-30 times efficient in free radical quenching activity than Trolex and other simple Phenolics (Hurrel et al., 1999). The plant pathogenic fungus Mycosphaerella mucunae is named for being first discovered on Mucuna. Fungal and mycotoxin contamination is also of main concern to minimize the economic losses and reduce the potential health risks to humans and livestock (Ueno, 2000). The seeds of Mucuna sloanei are susceptible to fungal and mycotoxin contamination. Obiakor-Okeke et al. (2014) isolated Aspergillus and Rhizopus species from cooked Mucuna sloanei seeds. Emiri and Chuku (2017) isolated Aspergillus, Pencillium and Rhizopus species from the same seed.

Mucuna sloanei is relatively under utilized food crops in Nigeria. Most often, cocoyam and melon are popularly used in Southern-Eastern Nigeria as soup thickener. Their high carbohydrate and oil content respectively could increase one's risk of weight gain. On the other hand, Mucuna sloanei which could be used as a substitute because of its high protein content is most often neglected. Despite the numerous nutritional and health benefits associated with the seed, it has been neglected. Hence there is dearth of information on its fungal contamination and biochemical changes induced by the fungal pathogen. This research is therefore aimed at investigating the biochemical changes in the seeds induced by pathogenic fungi. 


\section{Material and methods}

\section{Source of sample}

Dehulled healthy and partially rotted Mucuna sloanei seeds were purchased from a local market in Port Harcourt Metropolis. The research work was conducted at the mycology/plant pathology unit of the department of plant science and biotechnology, Rivers State University, Port Harcourt, Nigeria.

\section{Media preparation}

The medium used for fungal isolation was the Sabouroud Dextrose Agar (SDA). This was prepared by weighing $32.8 \mathrm{~g}$ of Sabouroud Dextrose Agar (SDA) into a $500 \mathrm{~mL}$ conical flask, distilled water $(500 \mathrm{~mL})$ was added into the flask with a measuring cylinder amended with chloromphemicol and stirred to homogenize. The mouth of the conical flask was plugged with sterile cotton wool and wrapped with foil. The conical flask with its contents was autoclaved for $15 \mathrm{~min}$ at $121^{\circ} \mathrm{C}$ at 15 PSI pressure. Sterile Petri dishes were prepared and the mixture dispensed into them while still hot and allowed to solidify.

\section{Isolation and identification of fungi from partially rotted $M$. sloanei seeds}

Five dehulled partially rotted seeds of Mucuna slonei used were washed in tap water, rinsed in distilled water and surface sterilized with $5 \%$ sodium hypochlorite for 5 min and rinsed twice in sterilized distilled water after which they were aseptically introduced into the SDA in Petri dishes equidistantly, in triplicate.

Pure cultures of fungi growing in mixtures were obtained thereafter. Pure cultures of the isolates were made after series of isolation. Microscopic examination of fungal isolates was carried out. The fungi were identified based on colour, spore morphology and the structure of the mycelia, according to the key of (Olds 1983, Samson et al., 1981). The fungi isolated Rhizopus stolonifer, Aspergillus flavus, Aspergilus niger, Penicillium italicum, Alternaria altermata, and Fusarium oxysporum were used for the study.

\section{Inoculation of $M$. sloanei seeds with test fungi}

One hundred grams of healthy M. sloanei seeds were weighed out and cleaned aseptically. The cleaned seed were then put into $25 \mathrm{~mL}$ conical flasks, plugged with sterile non-absorbent cotton wool and covered with the foil and then autoclaved at $121^{\circ} \mathrm{C}$ for 15 min at 15 PSI to eliminate any internal and external seed borne micro-organism (Ward and Diener, 1961). After autoclaving, the flasks were allowed to cool and $100 \mathrm{~mL}$ of sterile distilled water was added to each flask and shaken gently to wet all the seeds and to create a humid and conducive environment for the fungi to be inoculated and to have an even distribution. Each flask containing seeds was inoculated with a disc of 7 days old mycelium spores of each fungus obtained from the pure culture of fungi isolated from infected seeds. This was done with a $1.5 \mathrm{~cm}$ diameter sterile cork borer. The flasks were gently shaken for about 15 min to obtained uniform distribution of the mycelium among the seeds. The control flask received the same treatment, but there were no fungi added to it. The entire flasks which include the fungi inoculated and uninoculated seeds were incubated at room temperature in complete darkness for 14 days.

A total of 18 flasks were used, 3 flask replicate for each set of fungi inoculated seeds and seeds. They were incubated for 14 days in a dark incubated area. At the end of the incubation period, the flasks of each fungal treatment and flasks for control were harvested for biochemical analysis. The seeds in each flask were transferred into a preweighed watch glass, dried at $45^{\circ} \mathrm{C}$ for 24 hours and the spores and mycelia of the fungi removed by sieving (Ward and Diener, 1961). Biochemical analysis of various nutrient component, Moisture, Crude Lipid, Crude Protein, Crude Fiber, Ash and carbohydrate content in both fungi inoculated and uninoculated seeds at the incubation period of 14

Braz. J. Biol. Sci., 2020, Vol. 7, No. 15, p. 19-27. 
days were determined, also the effect of the fungi on the anti-nutrient content of the seed was carried out following procedures recommended by the Association of Official Analytical Chemists (AOAC, 1995). The results of each component were subjected to statistical analysis using the analysis of variance (ANOVA).

\section{Results}

The results of the proximate analysis of $M$. sloanei seeds inoculated with test fungi, and uninoculated (control) is presented in Table 1. The test fungi induced appreciated changes in the nutrient composition of the seed. There was significant increase $(\mathrm{P}<0.05)$ in moisture, ash, lipid and carbohydrate content of the seed inoculated with the test fungi compared with the uninoculated (control) seeds (Table 1). There was significant decrease $(\mathrm{P}<0.05)$ in fiber and protein content of the seeds inoculated with test fungi relative to the uninoculated (control). Significant differences also existed among the various test fungi in relation to the proximate composition of the seeds sample.

Table 1. Changes in the proximate composition of Mucuna sloanei seeds inoculated with test fungi.

\begin{tabular}{lcccccc}
\hline \multirow{2}{*}{ Test fungi } & \multicolumn{7}{c}{ Proximate composition $(\% \mathbf{W} / \mathbf{W}) / \mathbf{1 0 0} \mathbf{g}$} \\
\cline { 2 - 7 } & Moisture & Ash & Fiber & Lipid & Carbohydrate & Protein \\
\hline Uninoculated (control) & 10.60 & 3.00 & 3.30 & 8.10 & 48.60 & 21.80 \\
Rhizopus stolonifer & 14.20 & 3.60 & 1.80 & 9.15 & 49.70 & 21.50 \\
Aspergillus flavus & 13.20 & 3.40 & 1.70 & 9.00 & 51.70 & 21.00 \\
Aspergilllus niger & 12.50 & 3.20 & 2.50 & 8.50 & 50.80 & 20.50 \\
Penicillium italicum & 14.80 & 3.60 & 1.50 & 9.10 & 50.60 & 20.70 \\
Alternaria altermata & 14.50 & 3.50 & 1.80 & 10.50 & 50.30 & 19.50 \\
Fusarium oxysporum & 16.00 & 3.30 & 1.75 & 8.45 & 52.90 & 17.70 \\
LSD (P < 0.05) & 1.28 & 0.05 & 0.79 & 2.21 & 0.76 & 2.51 \\
\hline
\end{tabular}

Means are significantly different by LSD at $\mathrm{P}<0.05$.

Results of the changes in mineral content of M. sloanei seeds inoculated with test fungi is presented in table 2. There was a significant increase in the content of Calcium, Phosphorus and Sodium, while the Iron, Potassium and Magnesium decreased, relative to the uninoculated seed. Significant differences also occurred among the test fungi (Table 2).

Table 2. Changes in the mineral content of Mucuna sloanei seeds inoculated with test fungi.

\begin{tabular}{lcccccc}
\hline \multirow{2}{*}{ Test fungi } & \multicolumn{7}{c}{ Mineral Composition (w/w)/100g } \\
\cline { 2 - 7 } & Calcium & Iron & Phosphorus & Potassium & Sodium & Magnesium \\
Uninoculated (control) & 0.92 & 0.81 & 1.60 & 1.75 & 0.05 & 5.14 \\
Rhizopus stolonifer & 4.00 & 0.35 & 2.20 & 1.30 & 0.06 & 0.07 \\
Aspergillus flavus & 4.10 & 0.21 & 2.30 & 1.40 & 0.05 & 0.10 \\
Aspergillus niger & 3.90 & 0.30 & 2.40 & 1.50 & 0.04 & 0.08 \\
Penicilliun itallicum & 4.10 & 0.20 & 2.50 & 1.60 & 0.07 & 0.09 \\
Alternaria altermata & 3.80 & 0.25 & 2.15 & 1.40 & 0.09 & 0.10 \\
Fusarium oxysporum & 3.10 & 0.30 & 2.05 & 1.70 & 0.06 & 0.08 \\
LSD (P<0.05) & 0.91 & 0.03 & 0.05 & 0.01 & 0.02 & 0.01 \\
\hline
\end{tabular}

Means are significantly different by LSD at $\mathrm{P}<0.05$. 
Results on the changes in anti-nutrient (Phytochemical) as seen in table 3 showed that all the test fungi induced significant increase in all the anti-nutrient content evaluated. The test fungi differed significantly.

Table 3. Changes in anti-nutrient (phytochemical) content of M. sloanei seeds inoculated with test fungi.

\begin{tabular}{lcccc}
\hline \multirow{2}{*}{ Test fungi } & \multicolumn{4}{c}{ Phytochemical composition $(\% \mathbf{w} / \mathbf{w}) / \mathbf{1 0 0 g}$} \\
\cline { 2 - 5 } & Tannin & Saponin & Total oxalate & Cynoyenic glucoside \\
\hline Uninoculated (control) & 0.01 & 0.75 & 0.32 & 27.50 \\
Rhizopus solonifer & 0.35 & 1.70 & 1.26 & 30.40 \\
Aspergillus flavus & 0.23 & 1.85 & 1.13 & 32.30 \\
Aspergillus niger & 0.30 & 1.90 & 1.32 & 31.40 \\
Penicilliun itallium & 0.41 & 2.25 & 2.40 & 33.50 \\
Alternaria altermata & 0.30 & 2.10 & 2.30 & 36.10 \\
Fusarium oxysporum & 0.29 & 2.00 & 2.00 & 1.02 \\
LSD (P < 0.05) & 0.06 & 0.83 & 0.85 & \\
\hline
\end{tabular}

Means are significantly different by LSD at $\mathrm{P}<0.05$.

\section{Discussion}

Results on proximate composition revealed that moisture content increased significantly in fungi inoculated seeds relative to the uninoculated (Control) seed $(10.60 \%)$ Fusarium oxysporum caused the highest increase in moisture $(16.00 \%)$ followed by Penicillium italicum (14.80\%). The increase induced by fungi is due their utilization of the component of the seeds as food nutrients thereby producing water in the process. This is in agreement with the results obtained by Amienyo et al., (2016) who reported increase in moisture content of Sweet potato inoculated with storage fungi. Nwaukwu and IkechiNwogu (2012) also reported increase in moisture content of Dialium guineense inoculated with pathogenic fungi. Emiri and Enaregha (2019) reported similar result in Brachystegia eurycoma seeds infected with mycoflora. Isar and Ataga (2019) also reported an increased moisture in Jatropha curcas seed inoculated with Fusarium oxysporum and Macrophomina phaseolina in which they observed that Fusarium oxysporum caused the highest increase in moisture of the seed. The result from this study confirms their assertion. It thus suggests that deteriorative reactions occur more readily in seeds at higher moisture content and subsequently, this condition constitute hazard to the longevity of seed survival.

Similarly, ash increased significantly in seeds inoculated with the six test fungi compared to the uninoculated seed. Penicillium Italium and Rhizopus stolonifer were seen to cause the highest increase in ash content. This confirms the report of Nwaukwu and Ikechi Nwogu (2012) who reported increase in ash content of Dialium guineense inoculated with pathogenic fungi. Ataga and Umechuruba (1997) resolved that the increase could be attributed to the presence of minerals like Potassium and Phosphorus in the Mycelia of the fungi. This observation however negates the findings of Emiri and Enaregha (2019) who reported decrease in ash content of Brachystegia eurycoma seed infected with fungi and the findings of Etim et al (2014) who also reported a decrease in ash content in Mycoflora infected pods and seeds of cocoa (Theobroma cocao)

Lipid and carbohydrate content significantly increased in the seed samples inoculated with the six test fungi compared to uninoculated seeds. The various fungi isolates that caused the increase also differed significantly, with Alternaria altermata 
inducing the highest increase in lipid while Fusarium oxysporum induced highest increase in carbohydrate content. (Table 1). This confirms the assertion of of Isalar and Atagar (2019) who reported an increase in Lipid content of Jatropha curcas seed inoculated with fungi isolates. However, this observation negates the findings of Ogundero (1992), Nwaukwu and Ikechi-Nwogu (2012) who reported a decrease in ash content of Dialium guineense seeds inoculated with pathogenic fungi. The increase in lipids seems to suggest that these fungi have high lipase activities. Falaye and Fagbohun (2012) reported an increase in carbohydrate contents of groundnut (Arachus hypogea) infected with $R$. stolonifer and moulds. Umana et al. (2014), also reported increase in carbohydrate content of fungal infected seed of cocoa. Their findings agrees with this study.

Fiber and protein content depleted significantly in seeds inoculated with the test fungi relative to the uninoculated (control) seeds. Fusarium oxysporum depleted the protein content most while Aspergillus niger depleted fiber content most. This result agrees with the report of (Onifade et al., 2004) about a decrease in crude fiber content of Sweet potato flour enriched with A. niger. They also explained that the crude fiber tends to decrease during fermentation. The researchers concluded that the decrease in fiber was as a result of the fact that the fiber was being utilized by the fermentation microbes. In a similar development, Ndife et al. (2013) reported that fiber, and protein content of cocoa beans were seriously depleted when infected with Phytopthora capasici and Phytopthora megakanya. Shehu and Aliero (2010) have also reported that the infected onion leaf showed a significant decrease in the quantity of protein and fiber content. It could therefore be deduced that the relative decrease in fiber and protein in the inoculated seeds may be caused by the degradation and dissolution of the seed tissue by the fungi. The protein and fiber might have been broken down by the fungi into smaller inolecules that they absorbed (Nweke and Ibiam 2012).

The mineral content of $M$. sloanei seeds inoculated with the different test fungi revealed that there was a significant increase in calcium, phosphorus and sodium compared to the control. (Table 2). Significant differences also existed among the test fungi. Penicillium italicum and A. flavus took the lead in calcium. P. italicum also induced the highest increase in Phosphorus content, while Alternaria altermata took the lead in sodium. However, iron, potassium and magnesium content decreased in seed inoculated with all the test fungi, relative to the inoculated seeds. Apparently, $P$. italicum and $R$. stolonifer induced the highest decrease in iron and potassium, respectively, while $F$. oxysporum and $A$. niger induced the highest decrease in magnesium as seen in Table 2.

The values of the various mineral content in uninoculated seeds (control) are comparable to the values reported by Uhegbu et al. (2009) on nutritive and anti-nutritive properties of seeds of Barchystegia eurycoma and Detarium microcarpum. The increase in calcium, phosphorus and sodium agrees with the findings of Emiri and Enaregha (2019) on mycoflora associated with Brachystegia eurycoma seeds and their effects on the seed's biochemical properties. The decrease in iron, potassium and magnesium agrees with the report of Nwaukwu and Ikechi-Nwogu (2012) who reported a significant decrease in the same mineral composition of Dialium guineense inoculated with some pathogenic fungi.

There was significant increase in all the phytochemical content of (tannin, saponin, total oxalate and cynogenic glucoside) seeds inoculated with the test fungi compared to the uninoculated (control) seeds. P. italium took the lead in tannin, saponin and total oxalate, while $F$. oxysporum took the lead in cynogenic glucoside. It therefore suggest that the test fungi especially $P$. italicum induced an increase in the anti-nutrient (phytochemical) contents. Tannins have been shown to play very significant roles in human medicine and treatment of ailments (Addae-Mensah, 1992).

Saponins are known to have hypocholestrolemic as well as anti carcinogenic effect (Koratkar and Rao, 1997). This could confer some chemoprotection against heart disease to users of M. sloanei. 


\section{Conclusion}

The result obtained in this study emphasized that the activities of pathogenic fungi affects the nutritional and anti-nutritional (phytochemical) composition of the seeds of M. sloanei. The important mineral and phytochemical in the seeds may also be major contributors to the medicinal and nutritional value of the plant. These results lend the plant its credence as an ethomedicinal plant. The results from this study also revealed that Pencillium italicum appears to be a potent fungus haven recorded the highest increase in the tannin, saponin and oxalate content of M. sloanei seeds.

\section{Conflicts of interest}

Authors declare no conflict of interests.

\section{References}

Addae-Mensah, I. Towards a rational scientific basis for herbal medicine. A. Phytochemist's two decades contribution. An inaugural lecture delivered at the University of Ghana. Lgions: Ghana University Press Accra, 1992.

Adebowale, Y. A.; Adeyemi I. A.; Oshodi A. A. Variability in the physiochemical and antinutritional attributes of six Mucuna species. Food Chemistry, v. 89, p. 37-48, 2005. https://doi.org/10.1016/j.foodchem.2004.01.084

AOAC - Association of Official Analytical Chemists. Official methods of analysis. 16. ed. Virginia: Association of Official Analytical Chemists, 1995.

Ataga, A. E.; Umechuruba, C. I. Biochemical changes in African yam bean seeds caused by Botryodiplodia theobromae, Fusarium palidareseum and Penicilium cxaliam. Global Journal of Pure and Applied Science, v. 4, no. 4, p. 381-384, 1997.

Bressani, R. Factors influencing nutritive value in food grain legumes mucuna compared to other grain legume. In: Flores, B. M.; Ellitta, M.; Myhrman, R.; Carew, L. B.; Carsky, R. J. (Eds.). Food and feed from mucuna: Current uses and the way forward. Tegucipalma, Honduras: CIDICCO, CIEPCA, and World Hunger Research Center, 2002. p. 164-188.

Emiri, U. N.; Enaregha, E. B. Mycoflora associated with Brachystegia eurycoma (achi) seeds and their effects on the biochemical properties of the seed. International Journal of Bioscience and Biochemistry, v. 1, no. 2, p. 14-18, 2019.

Emiri, U. N.; Chuku E. C. Effect of boiling on the pathology and biochemical properties of Mucuna sloanei seeds. Journal of Advanced Studies in Agricultural, Biological and Environmental Sciences, v. 4, no. 4, p. 1-8, 2019.

Etim, J. U.; Ishoro, A. P.; Okay, E. N.; Akpan, J. B.; Effiong, P. F. Mycoflora associated with cocoa (Theobrema cacao) pods obtained in the field and their effects on seed nutritional content. Science Journal of Agricultural and Crop Research, v. 2, no. 12, p. 236-241, 2014.

Falaye, O. S.; Fagbohun, E. D. Effects of storage on the proximate, mineral composition and mycoflora of "Tinco" dried meat sold in Oshodi, Market Lagos State, Nigeria. Global Journal of Biological Science and Biotech, v. 1, no. 1, p. 54-58, 2012.

Graf, E.; Eaton, J. Antioxidant functions of phytic acid. Free Radical Biology and Medicine, v. 8, no. 1, p. 61-69, 1990. https://doi.org/10.1016/0891-5849(90)90146-a 
Hurrel, R. F.; Reddy, M.; Cook, J. D. Inhibition of non-iron absorption in man by polyphenolic containing beverages. British Journal of Nutrition, v. 81, p. 289-295, 1999. https://doi.org/10.1017/S0007114599000537

Isalar, O. F.; Ataga, A. E. The effect of Fusarium oxyspirium and Macroptomina phaseolina on the proximate composition of Jatropha curcas seed a biofuel plant. Journal of Biotechnology and Biomedicine, v. 29, no. 1, p. 1-8, 2019.

Koratkar, R.; Rao, A. V. Effect of soybean saponins on azoxymethane-induced preneoplastic lessons on the colon of mice. Nutrition and Cancer, v. 27, p. 206-209, 1997. https://doi.org/10.1080/01635589709514526

Ndife, J.; Bolaji, P.; Afoyabi, D.; Umezuruike, R. Production and quality evolution of cocoa products (plain cocoa powder and chocolate). American Journal of food and Nutrition, v. 3, no. 1, p. 31-38, 2013.

Nweke, C. N.; Ibiam, O. F. A. Studies on pre and post-harvest fungi associated with the soft rot of the fruit Anona muricata, and their effects on the nutrient content of the pulp. American Journal of food and Nutrition, v. 2, no. 4, p. 78-85, 2012.

Nwukwu, I. A.; Ikechi-Nwogu, C. Biochemical charges induced by the effect of six pathogenic fungi on Dialium guineense: Black velvet edible fruit. IOSR Journal of Pharmacy and Biology Sciences, v. 2, no. 4, p. 20-24, 2012. https://doi.org/10.9790/ 3008-0242024

Obiakor-Okeke, P. N.; Chikwendu, J. N.; Anozie, T. Effect of different processing methods on the chemical, functional and microbial properties of Mucuma sloanei seeds (ukpo). International Journal of Nutrition and Food Science, v. 3, no. 6, p. 551-559, 2014.

Ogundero, V. W. Hydrolysis of vegetable oils and triglycerides by thermotolerant and zoopathogenic species of Aspergillus from Nigeria palm produce. Mycopathogia, v. 77, p. 43-46, 1992. https://doi.org/10.1007/bf00588656

Olds, R. J. A colour atlas of Microbiology. 5. ed. London: Wolf Medical Publication, 1983.

Onifade, A. K.; Atum, H. N.; Adebolu, T. T. Nutrients enrichment of sweet potato (Ipomoea batatas L.). Global Journal of Pure and Applied Sciences, v. 10, no. 1, p. 31-36, 2004.

Richard, S. W.; Thompson L. U. Interaction and biological effects of phytic acid. In: Dhahidi, F. (Ed.). Anti-nutrients and phytochenicals in food. Washington DC: American Chemical Society, 1997. p. 294-312. (ACS Symposium Series, no. 662).

Samson, R. J.; Hoeskstra, E. S.; Van Oorschot, C. A. N. Introduction to food borne fungi. Netherlands: Central Bureau Coorschmmel Cultures, Publisher Institute of Royal, 1981.

Shehu, K.; Aliero, A. A. Effects of purple biotech infection on the proximate and mineral contents of onion leaf. International Journal Pharmacy Science Research, v. 1, no. 2, p. 131-133, 2010.

Ueno, Y. Risk of multi-exposure to natural toxins. Mycotoxins, v. 50, p. 13-22, 2000.

Ukachukwu, S. N.; Ezeagu, I. E.; Tarawall, G.; Ikeorgu, J. E. G. Utilization of Mucuna as a food. In: Flores, B. M.; Ellitta, M.; Myhrman, R.; Carew, L. B.; Carsky, R. J. (Eds.). Food and feed from mucuna: Current uses and the way forward. Tegucipalma, Honduras: CIDICCO, CIEPCA, and World Hunger Research Center, 2002. p. 180-287

Umana, E. J.; Ishoro, A. P.; Okey, E. N.; Akpan, J. B.; Effiong, P. F. Mycoflora associated with cocoa (Theobroma cacao) pods obtained in the field and their effects on seed nutritional contents. Journal of Agricultural and Crop Research, v. 2, no. 12, p. 236-241, 2014. 
Waryekeche, E.; Wakassa, V.; Murreithi, J. G. Effect of germination alkaline and acid soaking and boiling on the nutritional value of mature and immature mucuna (Mucuna pruriens) beans. Tropical and Subtropical Agroecosystems, v. 1, no. 2/3, p. 183-192, 2003.

Ward, H. S.; Diener, U. K. Biochemical changes in shelled peanuts caused by fungi. Effects of Aspergillus tamarii, four species of A. glaucus group and Penicillium citrinum. Phytopathology, v. 51, p. 244-250, 1961. 